\title{
Indian Ocean Studies: How Did We Get Here and Where Are We Going? A Historian's Perspective
}

\author{
Edward A. Alpers ${ }^{1}$ \\ University of California, Los Angeles
}

\begin{abstract}
In this article I present a survey of Indian Ocean Studies that focuses primarily on the development of its historiography after World War II from imperial history and its emergence as a distinct scholarly enterprise from the 1980s to the present day. In particular, I discuss some of the seminal monographs that have been published over the past two decades, suggesting the characteristics and challenges of modern historiography as reflected in these works. The article concludes by raising a number of lingering questions about definition and conceptualization, as well as suggesting ways ahead for future scholarship.
\end{abstract}

As recently as 2006, Kären Wigan, the coordinator of a major American Historical Review $(A H R)$ Forum that featured 'Oceans of History,' observed enthusiastically, 'Maritime scholarship seems to have burst its bounds; across the discipline, the sea is swinging into view.'2 She noted further that 'This $A H R$ Forum looks at one branch of this burgeoning scholarship: namely, studies that adopt a single, more or less bounded body of water as their focus or frame.' The Forum featured stimulating essays on the Mediterranean Sea, the Atlantic Ocean, and the Pacific Ocean by leading scholars, yet, as Professor Wigan lamented in a footnote, 'Regrettably, the equally rich historiography of the Indian Ocean is not covered in this forum. ${ }^{3}$ Surely this was a lost opportunity, one that the $A H R$ has not bothered to rectify over the past fifteen years, although it has featured a handful of more

\footnotetext{
${ }^{1}$ A slightly shorter version of this paper was given as the Henry Luce Lecture on the Indian Ocean for the NYU Shanghai, Center for Global Asia, on 26 March 2021. The recording of that presentation is archived at https://www.youtube.com/watch?v=OJewkdp1_tg. I am grateful to Tansen Sen for inviting me to give this talk, to Celina Hung for her introduction, and to Burkhard Schnepel for chairing the Zoom session. My thanks also to Dodie McDow for his excellent suggestions on an earlier draft of this talk, as well as the two reviewers for this journal. Finally, I am always in debt to my incisive editor, my wife, Annie.

2 Kären Wigan, "Introduction," The American Historical Review, 111, 3 (June 2006), 717.

${ }^{3}$ Ibid., 718 , fn.8.
}

(C) Edward A. Alpers. This is an Open Access article distributed under the terms of the Creative Commons License CC BY NC SA, which permits users to share, use, and remix the material provided they give proper attribution, the use is noncommercial, and any remixes/transformations of the work are shared under the same license as the original. 
focused research articles and a forum on Indian Ocean topics. ${ }^{4}$ In this article, I offer a survey that, while it does not focus exclusively on the historiography of the Indian Ocean, seeks to locate the broader scholarly literature across numerous disciplines in the humanities and social sciences on the Indian Ocean world (IOW) in an historical context and looks hopefully to the future of Indian Ocean Studies. Accordingly, I adopt a chronological approach that emphasizes the main interpretive tendencies and innovations that have developed in the scholarship over time.

\section{First Generation of Post-WWII Scholarship}

Where to begin? The earliest attempt to deal historically in a serious, if popular, account was penned not by a historian, but by a renowned world sailor, Alan Villiers, author of the well-known account of his travels from Kuwait to the Swahili coast aboard the Kuwaiti boom 'Triumph of Righteousness' in 1938. ${ }^{5}$ Although Villiers's Monsoon Seas: The Story of the Indian Ocean is largely forgotten by modern scholars, it is actually well-researched and informed by his own extensive experience of seeing things from the sea, thus giving him a quite different perspective than most sedentary scholars. ${ }^{6}$ In many respects, then, Villiers embodied the kind of interdisciplinary approach to Indian Ocean Studies that we in the academy today advocate. If pushed to name a pioneering study of Indian Ocean history, however, most contemporary historians would identify a volume by the prolific Archivist in Chief of Mauritius, Auguste Toussaint, whose understandable island-centric approach was published in French in 1961 and translated into English in 1966. ${ }^{7}$ But as it happens, in 1955 a French linguist working in Madagascar on the Malagasy language, Jacques Auber, published another overlooked history. ${ }^{8}$ Taken together, what these

\footnotetext{
${ }^{4}$ See: Sunil S. Amrith, "Tamil diasporas across the Bay of Bengal," AHR, 114, 3 (2009), 547-72; Sana Aiyar, "Anticolonial homelands across the Indian Ocean: The politics of the Indian diaspora in Kenya, ca. 1930-1950," AHR, 116, 4 (2011), 9871013; Sebastian R. Prange, "A trade of no dishonor: Piracy, commerce, and community in the western Indian Ocean, twelfth to sixteenth century," AHR, 116, 5 (2011), 1269-93; “AHR roundtable: History meets fiction in the Indian Ocean: On Amitav Ghosh's Ibis Trilogy," contributions by Clare Anderson, Gaurav Desai, Mark R. Frost, Pedro Machado, and Amitav Ghosh, AHR, 121, 5 (2016), 1521-65; Nile Green, "The waves of heterotopia: Toward a vernacular intellectual history of the Indian Ocean," AHR, 123, 3 (2018), 846-74.

${ }^{5}$ Alan Villiers, Sons of Sinbad (New York: Charles Scribner's Sons, 1940).

${ }^{6}$ Villiers, Monsoon Seas: The story of the Indian Ocean (New York: McGraw-Hill, 1952).

${ }^{7}$ Auguste Toussaint, Histoire de l'océan Indien (Paris: Presses Universitaires de France, 1961); Auguste Toussaint, History of the Indian Ocean, trans. June Guicharnaud (London: Routledge and Kegan Paul, 1966).

${ }_{8}^{8}$ Jacques Auber, Histoire de l'océan Indien (Tananarive: Soicété Lilloise d'Imprimerie de Tananarive, 1955). To my knowledge the only contemporary historians who have acknowledged Auber's book are: Pier M. Larson, "African diasporas and the Atlantic," in The Atlantic in Global History, 1500-2000, eds. Jorge Cañizares-Esguerra and Erik R. Seeman (Upper Saddle River, NJ: Prentice Hall, 2007), 132, 144 fn.13; Richard B. Allen, European Slave Trading in the Indian Ocean, 1500-1850 (Athens: Ohio University Press, 2014), 4 fn.16.
} 
pioneering studies suggest is that the Indian Ocean had not yet achieved the kind of wider recognition as a legitimate field of scholarship that it presently enjoys. Moreover, although certain scholars did recognize the significance of the Indian Ocean, they did so not as an object of study in itself, but within the context of some other historical unit of study.

Indeed, the Indian Ocean was not entirely ignored by a handful of imperial historians such as Holden Furber. Writing in the late 1940s about the English East India Company, Furber broke new ground in imperial historiography by emphasizing the importance of the Asian-dominated 'country trade' as underlying the company's commercial success. In so doing, he revealed himself to be an important observer of Indian Ocean trade in the late eighteenth century. ${ }^{9}$ By any measure, however, the leading proponent of an Indian Ocean-based historiography in the 1950s and 1960s was Charles R. Boxer, who happened also to be one of my Ph.D. thesis examiners at the University of London. Boxer was an exceptionally prolific scholar whose work spanned both the Atlantic and Indian Ocean worlds. But from our watery perspective, perhaps his three most significant contributions were The Great Ship from Amacon (1959), The Dutch Seaborne Empire (1965), and The Portuguese Seaborne Empire (1969). ${ }^{10}$ Although the focus of each of these books was on an aspect of European expansion, and the latter two titles were not exclusively focused on the Indian Ocean, Boxer was always alert to the hazards of seafaring and the significance of naval power in his scholarship. Also noteworthy during this period was Gerald Graham's study of Great Britain in the Indian Ocean during the first half of the nineteenth century, which specifically highlighted 'maritime enterprise' in its subtitle. ${ }^{11}$

In addition to a brace of studies by Toussaint and Furber that built upon their earlier work, ${ }^{12}$ perhaps the most significant scholarly contributions to Indian Ocean historiography in the 1970s were by Jean Aubin and Niels Steensgaard. Both focused on the post-1500 period of European maritime intrusion. Aubin's scholarship focused on his

\footnotetext{
${ }^{9}$ Holden Furber, John Company at Work: A study of European expansion in India in the late eighteenth century (Cambridge, MA: Harvard University Press, 1948).

${ }^{10}$ Charles R. Boxer, The Great Ship from Amacon; Annals of Macao and the old Japan trade (Lisboa: Centro de Estudos Históricos Ultramarinos, 1959); Charles R. Boxer, The Dutch Seaborne Empire, 1600-1800 (London: Hutchinson, 1965); Charles R. Boxer, The Portuguese Seaborne Empire, 1425-1825 (London: Hutchinson, 1969).

${ }^{11}$ Gerald S. Graham, Great Britain in the Indian Ocean: A study of maritime enterprise, 1810-1850 (Oxford: Clarendon Press, 1967). Interestingly, Graham was a colleague of Boxer at King's College London during these years. For a more recent study, see: Thomas R. Metcalf, Imperial Connections. India in the India Ocean arena,1860-1920 (Berkeley, CA: University of California Press, 2007).

${ }^{12}$ Auguste Toussaint, L'océan Indien au XVIII siècle (Paris: Flammarion, 1974); Holden Furber, Rival Empires of Trade in the Orient, 1600-1800. Europe and the world in the age of expansion, II (Minneapolis: University of Minnesota Press, 1976).
} 
careful analysis of both Portuguese and Indian Ocean language sources (mainly Arabic and Persian) for the sixteenth century. While his emphasis was on Asian centers of confrontation with the Portuguese, rather than on maritime affairs, his scholarship was certainly germane to Indian Ocean Studies. ${ }^{13}$ Steensgaard's major contribution was his thesis that there was a fundamental economic and institutional break in 1600 that marked the demise of the so-called "pedlar trade" that characterized Indian Ocean trade of both the pre-1500 period and the sixteenth-century Portuguese Estado da Índia as both the English and Dutch merchant companies surpassed the older commercial regime. ${ }^{14}$ What stands out, of course, is that all of this post-World War II Indian Ocean historiography is ultimately about European expansion, rather than the IOW on its own terms. For a distinct field of Indian Ocean Studies to emerge in its own right depended on a coming together of several larger factors, among these the refiguring of historical scholarship in a postcolonial world and the consequent development of World History as a field of inquiry and instruction.

\section{THE NeW Indian OCEAN HistoriograPhy}

From the mid-1970s, three important publications occurred that marked a new beginning in Indian Ocean studies. First was the appearance of a collection of papers presented at a 1967 Nairobi conference on 'East Africa and the Orient.' While the focus was on Africa, the scope of papers presented ranged across the Indian Ocean and included chapters on both Arabic and Chinese sources for East African history. ${ }^{15}$ This volume was followed by the proceedings of the initial meeting of the International Conference on Indian Ocean Studies (ICIOS), which was organized in August 1979 by Frank Broeze and Kenneth McPherson and convened at Perth, Western Australia, where both taught. During this period, Perth offered a unique venue both because of its outward orientation to the Indian Ocean and insular Southeast Asia, and as a viable meeting place when South Africa was still under apartheid rule and other Indian Ocean nations were mainly preoccupied with internal affairs. Conference proceedings were published in six volumes that covered

\footnotetext{
${ }^{13}$ Mare Luso-Indicum. Études et documents sur l'histoire de l'océan Indien et des pays riverains à l'époque de la domination portugaise (Centre de Recherches d'Histoire et de Philologie de la IV Section de l'École pratique des Hautes Études, Geneva: Librarie Droz), Tome I (1971); Tome II (1973); Tome III (1976); Tome IV (1980).

${ }^{14}$ Niels Steensgaard, Carracks, Caravans and Companies. The structural crisis in the European-Asian trade in the early $17^{\text {th }}$ Century (Lund: Studentlitteratur, 1973), republished as: The Asian Trade Revolution of the Seventeenth Century: The East India companies and the decline of the caravan trade (Chicago: University of Chicago Press, 1974).

${ }^{15} \mathrm{H}$. Neville Chittick and Robert I. Rotberg (eds.), East Africa and the Orient: Cultural syntheses in pre-colonial times (New York: Africana Publishing, 1975).
} 
environment and resources, trade and development, the history of commercial exchange and maritime transport, international politics, cultural exchanges and influence, and archives and resources for study. ${ }^{16}$ A year later, in 1980, UNESCO published the report and papers of a critical seminar on the Indian Ocean that it had organized at Port Louis, Mauritius in July 1974 as part of the planning process for its General History of Africa. ${ }^{17}$ According to the anonymous Introduction to this pioneering collection, 'the twofold purpose of the meeting was, first, to take stock of the present state of knowledge and, secondly, to co-ordinate several existing programmes and, possibly, to put forward proposals for a new pluricontinental and intercultural programme among the various research specialists and institutions concerned. ${ }^{18}$ It is worth noting, however, that even in a meeting devoted to the Indian Ocean, the term 'pluricontinental' reminds us that the focus remained land bound, rather than on the sea. The book is divided into four sections: 'Part I, Historical cultural and commercial contacts across the Indian Ocean; Part II, The settlement of Madagascar and neighbouring islands; Part III, Indian Ocean studies; Part IV, Meeting of experts.' Individual contributions included chapters that indicated the connections between different continental sub-regions of the IOW as they affected eastern Africa. Of particular note is the chapter by James de Vere Allen, 'A proposal for Indian Ocean studies,' in which he notes the importance of delineating 'a definition of the Indian Ocean as a study-area. ${ }^{\prime 19}$ Born in Kenya to Australian parents, Allen spent the early years of his academic career at Kuala Lumpur before he returned to East Africa and immersed himself in Swahili culture, giving him an Indian Ocean perspective that had eluded most previous scholars. ${ }^{20}$ In his brief chapter, Allen suggests 'three layers of unity.' These included, first, 'racial unity of a sort provided by Malay and other migrations; secondly, cultural unity radiating out from the Indian subcontinent; and, thirdly, the religious unity provided by Islam...'21 However problematic we may regard Allen's suggested layers, they nevertheless reveal an initial attempt to grapple with the challenge of conceptualizing the IOW and Indian Ocean studies. Equally, the ambitious, if not always realized, recommendations of the UNESCO experts show the way towards the proliferation of Indian Ocean studies scholarship that has developed since 1980.

\footnotetext{
16 The Indian Ocean in Focus: International conference on Indian Ocean studies (Perth, 1979).

${ }^{17}$ Historical Relations Across the Indian Ocean (Paris: UNESCO, 1980).

${ }^{18}$ Ibid., 9-10.

${ }^{19}$ Ibid., 138.

${ }^{20}$ Marc Horton, “James de Vere Allen 1936-1990,” Azania, 25 (1990), 108-9.

${ }^{21}$ Historical Relations Across the Indian Ocean, 140.
} 
ICIOS II took place five years later, establishing Western Australia as the leading Indian Ocean center for the study of the wider region. Like its multidisciplinary predecessor, papers presented at ICIOS II were collected in multiple photocopied volumes, in this case numbering seven. ${ }^{22}$ By this time, groundwork for a much more vigorous and self-conscious historiography was now emerging. Here the lead was taken by Indian economic historian Kirti Chaudhuri who, inspired by Fernand Braudel's hugely influential history of the Mediterranean Sea, in 1985 published his major contribution, Trade and Civilisation in the Indian Ocean. ${ }^{23}$ Chaudhuri's earlier work studied the English East India Company, but in this volume, he moved well beyond that earlier focus. Powerfully conceived and meticulously presented, Chaudhuri's work was nevertheless limited both by its periodization and by his relative negligence of Africa, a prejudice that he explicitly articulated in his much larger follow-up Indian Ocean volume five years later. ${ }^{24}$ Chaudhuri's pioneering volume was soon followed by single volume histories of the Indian Ocean by Patricia Risso and Ken McPherson. ${ }^{25}$ Trained as a Middle Eastern historian of the Gulf, Risso's approach mirrors Chaudhuri's in some respects, but focuses more tightly on Muslims, while also extending into the nineteenth century. Unlike both Chaudhuri's and Risso's interventions, McPherson provides a longue durée approach to the region's history, encompassing both its vast extent and its exceptional historical depth. As one of the ICIOS driving forces, it is no surprise that McPherson sought to write a more comprehensive history of the Indian Ocean. In the Preface to his book, he wrote that it 'evolved out of fifteen years of teaching undergraduate courses in South Asian and Indian Ocean history' and that 'the teaching of Indian Ocean history provided many challenges in establishing the concept of the region and presenting it to fellow Australians as part of their world. ${ }^{26}$ A more traditional, popular perspective that appeared at the same time is Richard Hall's Empires of the Monsoon. ${ }^{27}$ Approaching the history of the Indian Ocean from a different disciplinary perspective, Amitav Ghosh wove together documents from the Geniza trove of medieval Jewish documents with his own anthropological

\footnotetext{
${ }^{22}$ Second International Conference on Indian Ocean Studies (Perth, 1984).

${ }^{23}$ K.N. Chaudhuri, Trade and Civilisation in the Indian Ocean: An economic history from the rise of Islam to 1750 (Cambridge: Cambridge University Press, 1985).

${ }^{24}$ K.N. Chaudhuri, Asia Before Europe: Economy and civilisation in the Indian Ocean from the Rise of Islam to 1750 (Cambridge: Cambridge University Press, 1990).

${ }^{25}$ Kenneth McPherson, The Indian Ocean: A history of people and the sea (Delhi: Oxford University Press, 1993); Patricia Risso, Merchants \& Faith: Muslim commerce and culture in the Indian Ocean (Boulder: Westview Press, 1995).

${ }^{26}$ McPherson, The Indian Ocean, ix.

${ }^{27}$ Richard Hall, Empires of the Monsoon: A history of the Indian Ocean and its invaders (Hammersmith, London: HarperCollins, 1996), a sub-title that invokes the spirit of: Sir Reginald Coupland, East Africa and Its Invaders, from earliest times to the death of Seyyid Said in 1856 (Oxford: The Clarendon Press, 1938).
} 
research on modern Egypt to create a stimulating imagination of an IOW that is both rooted in and stands outside historical time. ${ }^{28}$ It remains a standard reading assignment for undergraduate courses in Indian Ocean history, raising challenging questions about worldview and methodology.

At the beginning of the current millennium, Mike Pearson published a landmark book that became the standard introduction to Indian Ocean history. ${ }^{29}$ As he wrote in his Introduction, "I want to write a more total history than has appeared so far." 30 Pearson's volume has many virtues, most notably his emphasis on the ocean itself and extensive quotes from travelers on its waters, but as he himself has noted, it largely ignores the Malay world. ${ }^{31}$ Based on a lifetime of scholarship on Zanzibar and the place of the Swahili coast in the wider IOW, Abdul Sheriff's Dhow Cultures of the Indian Ocean focused attention on the western Indian Ocean in the period before the Portuguese intrusion of Vasco da Gama. ${ }^{32}$ His thick historical description goes well beyond Chaudhuri's more limited economic approach, but it is still focused on what Pearson refers to as the Afrasian Sea. ${ }^{33}$ Without question, the most monumental of these contributions is the two volume history of the pre-1500 IOW by French agronomist, ethnographer, linguist, and historian, Philippe Beaujard. Totaling more than 1,400 pages of text, illustrations, notes, and sources, Beaujard ranges across the entire geography of the IOW from the $4^{\text {th }}$ millennium $\mathrm{BCE}$ to the fifteenth century CE. His approach is inspired by world-systems analysis that regards the IOW as its own world economy long before the rise of capitalism. Originally published in French in 2012, both volumes have since been revised and translated into English. ${ }^{34}$ Richly detailed, and about as comprehensive as one could wish, they stand as major reference works, whether or not one subscribes to world-systems analysis. ${ }^{35}$ At the other end of the spectrum is Sugata Bose's short, incisive study of the IOW in the modern

\footnotetext{
${ }^{28}$ Amitav Ghosh, In an Antique Land: History in the guise of a traveler's tale (New York: Vintage, 1994).

${ }^{29}$ Michel Pearson, The Indian Ocean (London and New York: Routledge, 2003).

${ }^{30}$ Ibid., 9.

${ }^{31}$ Ibid., 10. I am deliberately not including the contemporaneous text published a year after Pearson by Milo Kearney, The Indian Ocean in World History (New York and London: Routledge, 2004), which is a misguided and ill-informed effort that adds nothing to the developing historiography at this time; for a devastating review by Kenneth McPherson, see The Journal of Asian Studies, 64, 1 (2005), 226-8.

${ }^{32}$ Abdul Sheriff, Dhow Cultures of the Indian Ocean: Cosmopolitanism, commerce and Islam (New York: Columbia University Press, 2010).

${ }^{33}$ Pearson, The Indian Ocean, 13-14.

${ }^{34}$ Philippe Beaujard, Les Mondes de l'océan Indien. Tome 1: De la formation de l'état au premier système-monde afroeurasien (4e millénaire av. J.-C. $-6^{e}$ siècle ap. J.-C.). Tome 2: L'ocean Indien, au Coeur de l'Ancien Monde (7e $-15^{e}$ siècle) (Paris: Armand Colin, 2012); translated by the author as The Worlds of the Indian Ocean: A Global History, 2 vols. (Cambridge: Cambridge University Press, 2019).

${ }^{35}$ The short essay by medievalist Bruno Judic, L'océan Indien au Moyen Âge (Paris: Ellipses, 2008), is interesting, but derivative.
} 
era. ${ }^{36}$ By embracing an Indian perspective on the wider region, like Beaujard, Bose advocates a comprehensive vision of a global world that rejects its subordination to external forces, although his book is only marginally about the larger IOW. A decade after Pearson's remarkable book, I published my own attempt to capture the entirety of the Indian Ocean's historical experience in the context of world history. ${ }^{37}$ Most recently, Gwyn Campbell published an innovative, longue durée history of Indian Ocean Africa that emphasizes the interaction between environmental factors and human agency, while also suggesting an alternative chronology to most received Indian Ocean histories. ${ }^{38}$ No doubt, other variations on these contributions will be published by individual historians in years to come.

Meanwhile, the past two decades have witnessed a virtual explosion of scholarly articles, collections of essays, and single author monographs on different aspects of Indian Ocean history. What I think this phenomenon represents is the wider academic acceptance of World History as a historiographical field and the entrance of a new generation of scholars from both within and without the IOW. Greater scholarly interest in global comparative slavery and commodities were arguably also forces driving this explosion. Some focus on a particular sub-region of the IOW; some on a single commodity of regional trade; some on cultural exchange; some on religion, especially Islam, but also Buddhism; most do so within a restricted time frame. To name them all here would be tedious, but among the more noteworthy are influential books by a wide range of scholars. One important area for understanding the deep history of the Indian Ocean is archaeology. In general, most archaeological research is published in scientific journals and field reports, but there are a handful of important archaeological studies that have been published as books. Pioneering work dating back into the 1990s on seafaring and maritime history in ancient South Asian waters has been done by Himanshu Prabha Ray, who in her own work pays particular attention to the interconnections between Buddhist missionaries and commerce between South and Southeast Asia. ${ }^{39}$ An accessible presentation of the rich findings at the Roman Egyptian port of Berenike, which involved

\footnotetext{
${ }^{36}$ Sugata Bose, A Hundred Horizons: The Indian Ocean in the age of global empire (Cambridge, MA: Harvard University Press, 2006).

${ }^{37}$ Edward A. Alpers, The Indian Ocean in World History (New York: Oxford University Press, 2014).

${ }^{38}$ Gwyn Campbell, Africa and the Indian Ocean World from Early Times to Circa 1900 (Cambridge: Cambridge University Press, 2019).

${ }^{39}$ Himanshu Prabha Ray, The Winds of Change. Buddhism and the maritime links of early South Asia (New Delhi: Oxford University Press, 1994); Himanshu Prabha Ray, The Archaeology of Seafaring in Ancient South Asia (Cambridge:

Cambridge University Press, 2003); Himanshu Prabha Ray, Beyond Trade. Cultural roots of India's Ocean (New Delhi: Aryan Books International. 2015). See also Himanshu Prabha Ray (ed.), The Archaeology of Knowledge Traditions of the Indian Ocean World (Abingdon: Routledge, 2021).
} 
an international team of archaeologists, was published by Steven Sidebotham. ${ }^{40}$ The volume brings together exciting evidence on commodity exchange and cultural influences that connected this Red Sea port to the farther reaches of the western Indian Ocean. More typical of books on the ancient period are edited volumes that incorporate the voices of many of the individual scholars who worked on a site. Of particular significance for the Indian Ocean is a volume that reports on excavations on the island of Socotra, which although it lies off the Horn of Africa, is culturally and politically an extension of south Yemen. Most revealing about this research are the numerous graffiti and images that were found in the Hoq Cave, on the north side of the island, which document the passage of travelers from both northeastern Africa and western Asia ${ }^{41}$ Especially intriguing for its connections to the Swahili coast is the report of excavations at the medieval site of Sharma, Yemen, where evidence of a resident African population is attested by ceramics that were certainly imported from coastal East Africa. ${ }^{42}$

For the medieval period, we are fortunate to have a number of truly outstanding works. Both Roxani Margariti's careful study of thirteenth- and fourteenth-century Aden and Elizabeth Lambourn's extraordinary dissection of a single twelfth-century document to unpack the material culture of a Jewish merchant linking Egypt, Aden, and Malabar are impressively interdisciplinary and methodologically sophisticated. Both also demonstrate the evidentiary riches of the Geniza documentation that bear upon the so-called India trade of medieval Cairo. ${ }^{43}$ Focusing on the development of what he designates as 'monsoon Islam,' Sebastian Prange explores the link between merchants and the evolution of a specific Indian Ocean variety of Islam in Malabar from the twelfth into the sixteenth century. ${ }^{44}$ Although its focus is not on the Indian Ocean, the first volume of André Wink's

\footnotetext{
${ }^{40}$ Steven E. Sidebotham, Berenike and the Ancient Spice Route (Berkeley, CA: University of California Press, 2011).

${ }^{41}$ Ingo Strauch (ed.), Foreign Sailors on Socotra: The inscriptions and drawings from the cave Hoq (Bremen: Hempen Verlag, 2012).

${ }^{42}$ Axelle Rougeulle (ed.), Sharma. Un entrepôt de commerce medieval sur la côte du Hadramawt (Yémen, ca 980-1180), British Foundation for the Study of Arabia Monographs 17 (Oxford: Archaeopress, 2015).

${ }^{43}$ Roxani Eleni Margariti, Aden \& the Indian Ocean Trade: 150 Years in the life of a medieval Arabian port (Chapel Hill: The University of North Carolina Press, 2007); Elizabeth A. Lambourn, Abraham's Luggage: A social life of things in the medieval Indian Ocean world (Cambridge: Cambridge University Press, 2018). The primary sources of the India Book have been published in both English translation and modern Hebrew, for which see the Select Bibliography in Lambourn, Abraham's Luggage. For another historian who has made good use of the Geniza material for Indian Ocean history, see: Ranabir Chakravarti, "The commercial network of Gujarat in the light of the Jewish documentary Geniza (Eleventh-Twelfth Centuries)," in Transregional Trade and Traders: Situating Gujarat in the Indian Ocean from early times to 1900, eds. Edward A. Alpers and Chhaya Goswami (New Delhi: Oxford University Press, 2019), 123-40; Ranabir Chakrabarti, The Pull Towards the Coast and Other Essays: The Indian Ocean History and the Subcontinent before 1500 CE (Delhi: Primus Books, 2021).

${ }^{44}$ Sebastian R. Prange, Monsoon Islam. Trade and faith on the medieval Malabar coast (Cambridge: Cambridge University Press, 2018).
} 
exhaustive study of the Indo-Islamic world is firmly situated within the western IOW. ${ }^{45}$ Regrettably, there is no exact parallel for the eastern reaches of the IOW, but Tansen Sen's remarkable study of Buddhism in India-China relations, Derek Heng's history of SinoMalay maritime connections, and Kenneth Hall's history of Southeast Asia to 1500 all assign an important role to maritime trade. ${ }^{46}$

When we turn to what I consider to be essential works on the period after about 1500, we first encounter the work of two pioneers. Published as a posthumous collection of his essays in 2001, the body of work on Indian Ocean merchants by distinguished Indian historian Ashin Das Gupta spans essays dating as far back as the mid-1950s to the beginning of the current millennium. ${ }^{47}$ Read together, they reveal a restlessly inquisitive mind that sought to understand the place of Indian merchants in the IOW. His contributions serve as an important intellectual bridge between the scholarship of the second half of the twentieth century and the present, as is apparent from the regular citation of his work by younger scholars. Equally influential have been the many essays by Mike Pearson, some of which, covering a period from 1968 to 2001, are republished in a single volume. ${ }^{48}$ Among the current generation of Indian Ocean scholars, first books by Engseng Ho, trained as an anthropologist; Nancy Um, trained as an art historian; and historians Jeremy Prestholdt, Sebouh Aslanian, Pedro Machado, Matthew Hopper, Hideaki Suzuki, Fahad Bishara, Thomas McDow, and Christopher Low are among my favorites.

Ho's striking study of migration, family ties, and Islamic practice connecting the Hadramawt and the Malay Archipelago set a new standard for examining links between the western and eastern reaches of the IOW. ${ }^{49}$ By focusing on the interplay between trade and architecture at the Red Sea port of Mocha, Nancy Um opens up an entirely novel

\footnotetext{
${ }^{45}$ André Wink, Al-Hind. The Making of the Indo-Islamic World, Vol. 1: "Early Medieval India and the Expansion of Islam $7^{\text {th }}-11^{\text {th }}$ Centuries" (Boston and Leiden: Brill, 2002).

${ }^{46}$ Tansen Sen, Buddhism, Diplomacy and Trade: The Realignment of India-China Relations, 600-1400 (Honolulu: University of Hawai' ${ }^{\prime}$ Press, 2003); Derek Heng, Sino-Malay Trade and Diplomacy from the Tenth through the Fourteenth Century (Athens: Ohio University Research in International Studies, Southeast Asia Series No. 121, Ohio University Press, 2009); Richard Hall, A History of Early Southeast Asia. Maritime Trade and Societal Development, 100-1500 (Lanham, MD: Rowman \& Littlefield, 2011). For the post-1500 period, see Anthony Reid, Charting the Shape of Early Modern Southeast Asia (Singapore: Institute of Southeast Asian Studies, 2000), which includes essays previously published in the last quarter of the twentieth century.

${ }^{47}$ Uma Das Gupta (compiler), The World of the Indian Ocean Merchants 1500-1800. Collected essays of Ashin Das Gupta (New Delhi: Oxford University Press, 2001). See also: Rudrangshu Mukherjee and Lakshmi Subramanian (eds.), Politics and Trade in the Indian Ocean World. Essays in honour of Ashin Das Gupta (New Delhi: Oxford University Press, 1998). ${ }^{48}$ M.N. Pearson, The World of the Indian Ocean, 1500-1800. Studies in economic, social and cultural history (Aldershot: Ashgate Variorum, 2005).

${ }^{49}$ Engseng Ho, The Graves of Tarim: Genealogy and mobility across the Indian Ocean (Berkeley, CA: University of California Press, 2006).
} 
perspective on Indian Ocean history. ${ }^{50}$ As I noted on the back cover blurb for Prestholdt's arresting study of East African consumerism in the long nineteenth century, his book 'ingeniously stands the study of globalization and trade on its head.' For while historians of my generation had focused on trade and production, Prestholdt's work shifted the focus onto the essential role played by African taste. ${ }^{51}$ Aslanian's research on the Indian Ocean commercial network of Armenian merchants from New Julfa, Iran, which he designates as a 'circulation society,' makes visible both an extraordinary archive of primary source materials for regional history, but also the mechanisms of organizing trade within the Armenian community and the critical significance of trust in trade. ${ }^{52}$ Machado's analysis of commercial ties between Mozambique and Gujarat goes well beyond previous studies of how the organization of trade, production, financing in western India, and parallel African consumer demand worked together across the western Indian Ocean. ${ }^{53}$ Matthew Hopper locates his analysis of slavery in the Arabian Gulf in the context of both the western Indian Ocean and the rapidly developing globalization of the late nineteenth century, as does Suzuki on his work on slave traders. ${ }^{54}$ For his part, Bishara, who studied with Ho at Duke University, opens up an entirely new frontier of legal history as it applies to the commercial history of this same region. His work also demonstrates the value of previously unexamined Arabic documentation for the modern history of the Indian Ocean. ${ }^{55}$ Drawing upon a parallel body of Arabic documentation, McDow focuses on the role of debt linking both coastal and interior Oman and East Africa in the nineteenth century. ${ }^{56}$ In his presentation of late Ottoman Mecca, Low demonstrates that the Indian

\footnotetext{
${ }^{50}$ Nancy Um, The Merchant Houses of Mocha. Trade and architecture in an Indian Ocean port (Seattle and London: University of Washington Press, 2009). For a valuable study of Swahili architecture in the context of the Indian Ocean, see: Prita Meier, Swahili Port Cities. The architecture of elsewhere (Bloomington, IN: University of Indiana Press, 2016). Um's second book examines material culture of another Yemeni port-city: Nancy Um, Shipped But Not Sold: Material culture and the social protocols of trade during Yemen's sage of coffee (Honolulu: University of Hawai'i Press, 2017). See also: Ulrike Freitag, A History of Jeddah. The gate to Mecca in the nineteenth and twentieth centuries (Cambridge: Cambridge University Press, 2020).

${ }^{51}$ Jeremy Prestholdt, Domesticating the World. African consumerism and the genealogies of globalization (Berkeley, CA: University of California Press, 2008).

${ }^{52}$ Sebouh David Aslanian, From the Indian Ocean to the Mediterranean. The global trade networks of Armenian merchants from New Julfa (Berkeley, CA: University of California Press, 2011); the phrase is on 211.

${ }_{53}$ Pedro Machado, Ocean of Trade. South Asian merchants, Africa and the Indian Ocean, c.1750-1850 (Cambridge: Cambridge University Press, 2014).

${ }^{54}$ Matthew S. Hopper, Slaves of One Master: Globalization and slavery in the age of empire (New Haven: Yale University Press, 2015); Hideaki Suzuki, Slave Trade Profiteers in the Western Indian Ocean: Suppression and resistance in the nineteenth century (Cham, CH: Palgrave Macmillan, 2017).

${ }^{55}$ Fahad Ahmad Bishara, A Sea of Debt. Law and economic life in the western Indian Ocean, 1780-1950 (Cambridge: Cambridge University Press, 2017).

${ }^{56}$ Thomas F. McDow, Buying Time. Debt and mobility in the western Indian Ocean (Athens: Ohio University Press, 2018).
} 
presence at the heart of Islam rendered Mecca 'in many ways... as much an Indian or Indian Ocean space as it was an Arab, Ottoman, or Middle Eastern one. ${ }^{57}$

These two decades have also seen important monographs by three historians who have previously worked on Arabia and South Asia. Anne Bang studied Sufi networks linking Arabia and eastern Africa in the nineteenth and twentieth centuries. Her ability to trace family connections across the western Indian Ocean and the role of island communities in this history are important scholarly interventions. ${ }^{58}$ Building on his own earlier studies of Sufism in South Asia, Nile Green reconstructed the emergence of a novel variety of urban Islam that developed in nineteenth-century Bombay and expanded across the western Indian Ocean to South Africa. Green's conceptualization of how modernity, Islam, and mobility across the Indian Ocean interact offers a most stimulating gateway for future research. ${ }^{59}$ Sunil Amrith combined environmental factors with the more familiar topic of labor migration in his notable analysis of the Bay of Bengal. Not least of his contributions in this book is that it offers a coherent vision of this critical sea within the wider Indian Ocean, so often dominated by studies of the western Indian Ocean. ${ }^{60}$

The eastern frontier of the IOW is also the focus of two remarkable books by Ronit Ricci. The first of these examines Islamic literature and conversion in South and Southeast Asia and introduces the important concept of an Arabic cosmopolis. Her latest book reverses this direction by looking at Malay diaspora and writing in Sri Lanka. ${ }^{61}$ Islamic pilgrimage across the Indian Ocean is the subject of Eric Tagliacozzo's multi-faceted text on the hajj from Southeast Asia to Arabia. ${ }^{62}$ Kerry Ward expands our appreciation of

\footnotetext{
${ }^{57}$ Michael Christopher Low, Imperial Mecca. Ottoman Arabia and the Indian Ocean Hajj (New York: Columbia University Press, 2020), Kindle edition, quoted at Locations 299-300/11142.

${ }^{58}$ Anne K. Bang, Sufis and Scholars of the Sea. Family networks in East Africa, 1860-1925 (London: Routledge Curzon, 2003); Anne K. Bang, Islamic Sufi Networks in the Western Indian Ocean (c. 1880-1940): Ripples of reform (Boston: Brill, 2014).

${ }^{59}$ Nile Green, Bombay Islam. The religious economy of the West Indian Ocean, 1840-1915 (Cambridge: Cambridge University Press, 2011). An entirely different historiographical approach can be seen in the encyclopedic works of Dutch historian R.J. Barendse, whose books on the western Indian Ocean in the seventeenth and eighteenth centuries, despite a lack of coherence and production mistakes, are important sources of detailed information. R.J. Barendse, The Arabian Seas. The Indian Ocean world of the seventeenth century (Armonk, NY: M.E. Sharpe, 2002); R.J. Barendse, Arabian Seas, 17001763 (Leiden: Brill, 2009), 4 volumes, the first of which is specifically titled "The western Indian Ocean in the eighteenth century."

${ }^{60}$ Sunil S. Amrith, Crossing the Bay of Bengal. The furies of nature and the fortunes of migrants (Cambridge, MA: Harvard University Press, 2013).

${ }^{61}$ Ronit Ricci, Islam Translated. Literature, conversion, and the Arabic cosmopolis of South and Southeast Asia (Chicago: University of Chicago Press, 2011); Ronit Ricci, Banishment and Belonging. Exile and diaspora in Sarandib, Lanka and Ceylon (Cambridge: Cambridge University Press, 2019).

${ }^{62}$ Eric Tagliacozzo, The Longest Journey. Southeast Asians and the pilgrimage to Mecca (Oxford; Oxford University Press, 2013). See also: Eric Tagliacozzo (ed.), Southeast Asia and the Middle East. Islam, movement, and the longue durée (Stanford: Stanford University Press, 2009).
} 
imperial networks by linking Dutch Batavia to Sri Lanka and the Cape through an analysis of penal exile and Islamic networks. ${ }^{63}$ Beyond connections between Southeast Asia and the western reaches of the Indian Ocean, there is also a long history of maritime relationships with South China. Studies of the so-called Nanhai trade were pioneered by senior Chinese historian Wang Gungwu at the turn of the millennium. ${ }^{64}$ Over the past two decades a series of edited volumes have pursued various aspects of commerce and maritime history in the South China Sea, including its links to the IOW. ${ }^{65}$ One aspect of these studies is clearly the migration of Chinese merchants and laborers out into the IOW. To what extent this renewed interest in the Indian Ocean among China scholars may mirror the geopolitical forces driving China's Belt and Road Initiative remains an intriguing hypothesis.

The previously neglected Indian Ocean diaspora from Madagascar, spanning the southwest Indian Ocean, is at the center of the late Pier Larson's remarkable work on vernacular language and creolization that is based on a unique corpus of documents written in Malagasy ${ }^{66}$ Larson's initiative clearly reflected his personal history of growing up in Madagascar and becoming a historian of slavery and the slave trade. ${ }^{67} \mathrm{In}$ this context, Richard Allen's account of European slave trading in the Indian Ocean, which is constructed from his extensive research in a wide range of archives and explores the shipment of Malagasy, African, Indian, and Southeast Asian captives, marks an important benchmark in Indian Ocean studies. ${ }^{68}$ From a wider perspective, UNESCO's Slave Route Project, launched in 1994, has encouraged the study of the global African Diaspora and complemented the trend towards world history in academia. Turning to a different Indian Ocean diaspora, although there are many studies of Indians in Africa by both historians

\footnotetext{
${ }^{63}$ Kerry Ward, Networks of Empire: Forced migration in the Dutch East India Company (Cambridge: Cambridge University Press, 2009).

${ }^{64}$ Gungwu Wang, The Nanhai Trade. Early Chinese trade in the South China Sea (Singapore: Times Academic Press, 1998; Eastern Universities Press, 2003).

${ }^{65}$ Angela Shottenhammer (ed.), The Emporium of the World: Maritime Quanzhou, 1000-1400 (Leiden: Brill, 2001); Wang Gungwu and Ng Chin-keong (eds.), Maritime China in Transition, 1750-1850 (Wiesbaden: Harrassowitz, 2004); Angela Shottenhammer and Roderich Ptak (eds.), The Perception of Maritime Space in Traditional Chinese Sources (Wiesbaden: Harrassowitz, 2006); Angela Shottenhammer (ed.), The East Asian Maritime World, 1400-1800. Its fabrics of power and dynamics of exchanges (Wiesbaden: Harrassowitz, 2007); Angela Shottenhammer (ed.), The East Asian Mediterranean. Maritime crossroads of culture, commerce and human migration (Wiesbaden: Harrassowitz, 2008); Eric Tagliacozzo and Wen-Chin Chang (eds.), Chinese Circulations. Capital, commodities, and networks in Southeast Asia (Durham, NC: Duke University Press, 2011); Robert J. Antony and Angela Schottenhammer (eds.), Beyond the Silk Roads. New discourses on China's role in East Asian maritime history (Wiesbaden: Harrassowitz, 2017);

${ }^{66}$ Pier M. Larson, Ocean of Letters. Language and creolization in an Indian Ocean diaspora (Cambridge: Cambridge University Press, 2009).

67 “Historian Pier Larson dies at 58," https://hub.jhu.edu/2020/07/28/pier-larson-obituary/ [Accessed 2 Mar. 2021 ].

${ }^{68}$ Richard B. Allen, European Slave Trading in the Indian Ocean, 1500-1800 (Athens, OH: Ohio University Press, 2014).
} 
and social scientists, two studies by literary scholars of links between India and Africa emphasize the larger Indian Ocean context in exciting new ways. Gaurav Desai's wideranging analysis of a diverse body of Indian travel writing on East Africa demonstrates the great utility of adopting a history of literature perspective on this complicated history. ${ }^{69}$ No less thought provoking is Isabel Hofmeyr's literary analysis of Gandhi's South African newspaper, Indian Opinion, which not only locates this enterprise in a larger Indian Ocean context, but also reveals Gandhi's ideas about how to convey information. ${ }^{70}$

In a short, but provocative book, historian Antoinette Burton brings her sensitivity to imaginative literature to bear on Indian attitudes towards Africa and Africans. ${ }^{71}$ Here it is worth noting the major contributions of French historian Claude Markovits, who writes in fascinating detail about the global diaspora of South Asian merchants, indentured laborers, and sepoys beyond the Indian Ocean to both the Atlantic and Pacific worlds. ${ }^{72}$

Not to be overlooked in any survey of Indian Ocean Studies are seminal works on historic traditions of shipbuilding and sailing ships. The earliest of these by Dutch anthropologist A.H.J. Prins dates to 1965 and provides a wealth of observed detail on the maritime culture of Lamu, Kenya. ${ }^{73}$ In the current century, Maltese Arabist Dionisius Agius has published several exceptionally important monographs about dhows in the Gulf and Red Sea, as well as another on classic Islamic shipping. Taken together they comprise a remarkable body of work that is both technically and culturally astute. ${ }^{74}$ Although no exact parallels to Agius' output on dhows exists for other India Ocean ship traditions, studies of traditional shipbuilding and ships in the eastern Indian Ocean are one of the major areas of interest of French archaeologist Pierre-Yves Manguin, who has written a series of stimulating papers as book chapters and journal articles. ${ }^{75}$

\footnotetext{
${ }^{69}$ Gaurav Desai, Commerce with the Universe. Africa, India, and the Afrasian Imagination (New York: Columbia University Press, 2013).

${ }^{70}$ Isabel Hofmeyr, Gandhi's Printing Press. Experiments in slow reading (Cambridge, MA: Harvard University Press, 2013).

${ }^{71}$ Antoinette Burton, Africa in the Indian Imagination. Race and the politics of postcolonial citation (Durham, NC: Duke University Press, 2016).

${ }^{72}$ Claude Markovits, The Global World of Indian Merchants, 1750-1947: Traders of Sind from Bukhara to

Panama (Cambridge: Cambridge University Press, 2000); Claude Markovits, India and the World: A history of connections, c 1750-2000 (Cambridge: Cambridge University Press, 2021).

${ }^{73}$ A.H.J. Prins, Sailing from Lamu. A study of maritime culture in Islamic East Africa (Assen: Van Gorcum, 1965).

${ }^{74}$ Dionisius A. Agius, In the Wake of the Dhow. The Arabian Gulf and Oman (Reading: Ithaca, 2002); Dionisius A. Agius, Seafaring in the Arabian Gulf. The people of the dhow (London: Kegan Paul, 2005); Dionisius A. Agius, Classic Ships of Islam. From Mesopotamia to the Indian Ocean (Leiden and Boston: Brill, 2008); Dionisius A. Agius, The Life of the Red Sea Dhow. A cultural history of seaborne exploration in the Islamic World (London: I.B. Taurus, 2019).

${ }^{75}$ See: Pierre-Yves Manguin, "Austronesian shipping in the Indian Ocean: From outrigger boats to trading ships," in Early Exchange between Africa and the Wider Indian Ocean World, ed. Gwyn Campbell (Houndsmill: Palgrave Macmillan, 2016), 51-76 and numerous earlier essays listed in his References.
} 
In addition to these and many other fine monographs that have appeared since the explosion of historical scholarship on the Indian Ocean over the past two decades, I should acknowledge the importance of several influential collections of essays that have also appeared during this surge of interest in the Indian Ocean. Critical factors in this category of collective scholarship are the joining of forces by like-minded scholars and the widely acknowledged appreciation that studying the Indian Ocean is necessarily a collaborative effort that requires multiple disciplines, methodologies, and languages. Indeed, an important feature of many of these volumes of collected essays is that their contributors include historians, social scientists, and humanists, broadly defined. A major conference in India produced a collection of essays that range across the entire region, including several on often-ignored monetary issues. ${ }^{76}$ Including cultural studies as well as various historical approaches and a section on island-ness is the first publication in a new Indian Ocean series from South Africa. ${ }^{77}$ Yet another stimulating collection of essays that grapples with some of the larger conceptual issues in Indian Ocean studies was organized in Zanzibar in $2008 .^{78}$ At the same time, collections on specific aspects of research or themes have generated much scholarly interest, as in the case of those focusing on China's maritime history noted above. One of the most influential, and controversial, collections emphasizes the cosmopolitan character of Indian Ocean Islam. ${ }^{79}$ Indicative of the rapidly changing scholarship on the IOW is a volume that challenges generations of land-based Indian historiography by arguing for the influence of the Indian Ocean on the shaping of early modern India. ${ }^{80}$ This shift in perspective on Indian history has been a long time coming; one can see elements in the early works of historians like Das Gupta and Pearson, among others. But like the possible subtle influence of the Belt and Road Initiative on China scholars, might not the Indian response to Indian Ocean maritime leadership be at work here, as well ${ }^{81}$ Many of the conferences organized by Gwyn Campbell's Indian

\footnotetext{
${ }^{76}$ Himanshu Prabha Ray and Edward A. Alpers (eds.), Cross Currents and Community Networks. The history of the Indian Ocean world (New Delhi: Oxford University Press, 2007). For a volume devoted to currency issues, see: Steven Serels and Gwyn Campbell (eds.), Currencies in the Indian Ocean World (Houndsmill: Palgrave Macmillan, 2019).

${ }^{77}$ Pamila Gupta, Isabel Hofmeyr, Michael Pearson (eds.), Eyes Across the Water. Navigating the Indian Ocean (Pretoria: Unisa Press, 2010).

${ }^{78}$ Abdul Sheriff and Engseng Ho (eds.), The Indian Ocean. Oceanic connections and the creation of new societies (London: Hurst, 2014).

${ }^{79}$ Edward Simpson and Kai Kresse (eds.), Struggling with History. Islam and cosmopolitanism in the western Indian Ocean (London: Hurst, 2007).

${ }^{80}$ Pius Malekandathil (ed.), The Indian Ocean in the Making of Early Modern India (New Delhi: Manohar, 2016).

${ }^{81}$ For the ripples across the IOW that this rivalry has produced, see the special issue of the Journal of the Indian Ocean Region 17, 1 (2021), "Between the elephant and the dragon: Small states and India-China rivalry in the Indian Ocean region;" Rila Mukherjee, "India in the Indian Ocean World. From the Earliest Times to 1800 CE” (Cham, CH: Springer, forthcoming).
} 
Ocean World Centre at McGill University in Montréal, Canada have produced specific theme volumes that include much fascinating material that is published in an Indian Ocean World Series by Palgrave Macmillan. Some of these address familiar topics like trade and networks of connectivity, although often in innovative ways, as in the case of animal trade. ${ }^{82}$ Ohers raise novel themes such as medicine, islands, knowledge, and disease. ${ }^{83}$ Ohio University Press is home to a parallel Indian Ocean series that also includes both individual monographs, like Series Editor Richard Allen's survey on the European slave trade noted previously and two important collections of essays. The first of these brings together historians and archaeologists to explore both methodological and historical linkages; the second examines one of the principal commodities of Indian Ocean tradepearls - from a number of sites and perspectives. ${ }^{84}$ An emerging area of scholarly focus, one that also engages with contemporary politics on a global scale, is cultural heritage. Valuable volumes of essays have been edited by now familiar Indian Ocean hands Himanshu Prabha Ray, Burkhard Schnepel, and Tansen Sen. ${ }^{85}$ Finally, I want also to mention an important collection of essays on slavery and slave trade in the Indian Ocean World that is published in French and is sometimes overlooked in an overwhelmingly Anglophone Indian Ocean literature. Apart from its many individual case studies, this

\footnotetext{
${ }^{82}$ Among these, see: Michael Pearson (ed.), Trade, Circulation, and Flow in the Indian Ocean World (Houndsmill, Basingstoke: Palgrave Macmillan, 2015); Campbell (ed.), Early Exchange between Africa and the Wider Indian Ocean World; Pedro Machado, Sarah Fee, and Gwyn Campbell (eds.), Textile Trades, Consumer Cultures, and the Material Worlds of the Indian Ocean (Houndsmill: Palgrave Macmillan, 2018); Angela Schottenhammer (ed.), Early Global Interconnectivity across the Indian Ocean World, Vol. I, "Commercial structures and exchanges" (Houndsmill: Palgrave Macmillan, 2019); Martha Chaiklin, Philip Gooding, Gwyn Campbell (eds.), Animal Trade Histories in the Indian Ocean (Cham, CH: Palgrave Macmillan, 2020).

${ }^{83}$ Anna Winterbottom and Facil Tesfaye (eds.), Histories of Medicine and Healing in the Indian Ocean World, 2 volumes (Houndsmill: Palgrave Macmillan, 2016); Burkhard Schnepel and Edward A. Alpers (eds.), Connectivity in Motion. Island hubs in the Indian Ocean World (Houndsmill: Palgrave Macmillan, 2018); Sara Keller (ed.), Knowledge and the Indian Ocean. Intangible networks of western India and beyond (Houndsmill: Palgrave Macmillan, 2019); Angela Schottenhammer (ed.), Early Global Interconnectivity across the Indian Ocean World, Vol. II, "Exchange of ideas, religions, and technologies" (Houndsmill: Palgrave Macmillan, 2019); Gwyn Campbell and Eva-Maria Knoll (eds.), Disease Dispersion and Impact in the Indian Ocean World (Houndsmill: Palgrave Macmillan, 2020).

${ }^{84}$ Krish Seetah (ed.), Connecting Continents. Archaeology and history in the Indian Ocean World (Athens: Ohio University Press, 2018); Pedro Machado, Steve Mullins, and Joseph Christensen (eds.), Pearls, People, and Power. Pearling and Indian Ocean worlds (Athens: Ohio University Press, 2020). See also the forthcoming Ohio University Press volume coedited by Burkhard Schnepel and Julia Verne on "Cargoes in motion-materiality and connectivity in the Indian Ocean." ${ }^{85}$ Himanshu Prabha Ray (ed.), Bridging the Gulf: Maritime cultural heritage of the western Indian Ocean (New Delhi: Manohar, 2016); Burkhard Schnepel and Tansen Sen (eds.), Travelling Pasts: The politics of cultural heritage in the Indian Ocean world (Leiden: Brill, 2019). For background, see: Jonathan R. Walz and Sunil Gupta, "Report on the first conference on Indian Ocean heritage: Indian Ocean heritage, an emerging concept, organized by the French Ministry of Cultural Affairs and its affiliates, in Saint-Denis, Réunion, 2-4 November 2011," Journal of Indian Ocean Archaeology, 7 (2011), 122-8.
} 
volume is graced by two outstanding overview chapters by one of its editors, Henri Médard. ${ }^{86}$

\section{Characteristics and Challenges of Modern Historiography: How TO ORganize OUR THINKING?}

Any historian who ventures to work on the IOW must recognize at once that it is a multilingual space and that the sources for understanding its past are both scattered and, in many cases, still to be discovered. Indeed, for inhabitants of the historic IOW, heteroglossia was arguably the norm, rather than the exception. In addition to the many languages - ancient and modern, Asian, African, and European - that might be consulted, other sources upon which the historian draws include archaeology, historical linguistics, ethnography, and genetics. These sources are by no means evenly distributed: for example, there is a much richer archaeological record for the Swahili coast than for insular Southeast Asia. Imaginative literature and oral tradition may also be valuable sources depending on the time and place being studied.

Having presented what I consider to be a body of important works, mostly by historians, on the IOW, I now want to explore larger questions of definition and conceptualization as they might help to shape our future thinking. At the time of this writing, in fact, there is a virtual explosion of webinars and online conferences that are pushing the limits of Indian Ocean Studies in most promising ways. There are also a number of new institutional initiatives devoted to Indian Ocean Studies that are taking shape across the globe. But before I turn to these, let me say something about the various ways in which historians have sought to organize our thinking about the Indian Ocean world.

Among first order concerns have been effort to define the spatial dimensions of the IOW, quite apart from the larger question of how far the Indian Ocean extends. The most fertile of these imaginings has been Mike Pearson's notion of littoral society, which he first proposed in 1985 and reconsidered in a characteristically thought-provoking way in 2006. ${ }^{87}$ Pearson argued that these seaward-looking societies shared more in common with

\footnotetext{
${ }^{86}$ Henri Médard, Marie-Laure Derat, Thomas Vernet, Marie Pierre Ballarin (eds.), Traites et Esclavages en Afrique Orientale et dans l'Océan Indien (Paris: Karthala, 2013); 31-118 for Médard's chapters. For another rich collection of essays in French, see : Norbert Dodille (ed.), Idées et Représentations Coloniales dans l'Océan Indien (Paris: Presses de l'Université Paris-Sorbonne, 2009).

${ }^{87}$ Michael Pearson, "Littoral society: The case for the coast," The Great Circle, 7, 1 (1985), 1-8, reprinted in Pearson, The World of the Indian Ocean, Chapter VI; Michael Pearson, "Littoral society: The concept and the problems," Journal of World History, 17, 4 (2006), 353-73. For a more detailed discussion of how Pearson's ideas about littoral society evolved
} 
each other than they did with those communities in their continental hinterlands, although his later essay complicates this fundamental concept. Nevertheless, the idea of 'littoral society' has unquestionably taken hold among historians of the IOW, myself included ${ }^{88}$ Both Ken McPherson and Sugata Bose have suggested broad concepts for understanding the IOW that move away from notions of land-based civilizations that Chaudhuri emphasized. McPherson preferred the idea of 'culture zones' with boundaries that featured a 'porous frontier. ${ }^{89}$ Bose suggests the equally useful idea of the IOW as an 'interregional arena' for studying this vast world region. ${ }^{90}$

A different way to approach the IOW is to think beyond the monsoon cycle to incorporate other environmental factors and their human interactions, as Campbell does in his history of Indian Ocean Africa. Sheriff includes a valuable analysis of regional geographies in his book on dhow cultures, where he emphasizes the distinct, yet complementary zones of the Swahili coast, what he calls 'the intermediate desert zone,' and the western Indian seaboard.

Periodization is another tried and true organizing principle that continues to exercise historians. Although his intellectual inspiration for Trade and Civilisation in the Indian Ocean was Fernand Braudel's monumental history of the Mediterranean Sea, Braudel's concept of longue durée receives only brief mention by Chaudhuri, who begins his study with the rise of Islam. ${ }^{91}$ Whereas Pearson and I write about the deep history of the IOW in our general texts, and Gwyn Campbell begins his study of 'early times' in Indian Ocean Africa as far back as c.300 BCE, the undoubted champion of a detailed approach to the distant past of the IOW is Philippe Beaujard. Still, few seek to cover the whole span of historical experience from such early eras into the current era. In my own case, capturing this period was certainly the most challenging chapter for me to write.

More immediate to many historians are the finer questions of periodization that help us to define critical historical transitions. Clearly, the rise of Islam and the coming of the Portuguese and their successors are widely understood to be such important transitions, but how best to define such amorphous and mutable terms as 'ancient' and 'medieval,' or

over these two decades, see: Edward A. Alpers, "From littoral to ozone: On Mike Pearson's contributions to Indian Ocean history," Journal of Indian Ocean World Studies, 2 (2018): 12-24.

${ }^{88}$ Edward A. Alpers, "Littoral society in the Mozambique Channel," in Cross Currents, eds. Ray and Alpers, 123-141, reprinted in Edward A. Alpers, East Africa and the Indian Ocean (Princeton: Markus Wiener, 2009), 167-80, 230-4.

${ }^{89}$ McPherson, The Indian Ocean, 3-8.

${ }^{90}$ Sugata Bose, "Space and time on the Indian Ocean rim: Theory and history," in Modernity and Culture from the Mediterranean to the Indian Ocean, eds. Leila Tarazi Fawaz and C.A. Bayly (New York: Columbia University Press, 2002), 365-87, which is re-worked as the first chapter in his A Hundred Horizons, 1-35.

${ }^{91}$ Chaudhuri, Trade and Civilisation, 1-2, 21. 
'premodern,' and 'modern,' in an Indian Ocean context? Do such temporal categories speak to each other, facilitate or hinder understanding? For example, Campbell argues vigorously against the notion of 'early modern' in an IOW context because of its subordination to European periodization categories. ${ }^{92}$ Or does it make better analytical sense to think of a 'long eighteenth century,' as Prasannan Parthasarathi and Giorgio Riello contend, rather than a 'long nineteenth century,' as I have suggested ? $^{93}$

One of the most persistent tropes for thinking about the IOW is cosmopolitanism, which has many academic adherents. To be sure, there are many cosmopolitan features across the IOW, most notably as they pertain to urban areas. But as I have written elsewhere, I am skeptical of applying cosmopolitanism as an all-encompassing theory or even rubric to the entire region across all time and space. ${ }^{94}$ I prefer the less comprehensive, more complicated notion of translocality advocated by geographer Julia Verne, among others. ${ }^{95}$ Historian Nile Green advocates a complementary theoretical perspective in heterotopia, by which he envisions the Indian Ocean as an 'arena of difference. ${ }^{96}$ Green has also noted the continuing value of a comparative perspective, which is implicit in much writing on the IOW. ${ }^{97}$ Rather than comparison, Sanjay Subrahmanyam's conceit of 'connected histories' has become a powerful organizing principle for many historians in recent years. ${ }^{98}$ Still another theoretical model that has attracted much attention from Indian Ocean scholars is network theory. To what extent the strict applicability of this theory, as opposed to a less rigid appreciation of the many different networks that crisscross the IOW, may appeal depends very much on the individual. What each of these competing ideas reveals beyond question is that the Indian Ocean has been and continues to be an

\footnotetext{
${ }^{92}$ Gwyn Campbell, "Africa, the Indian Ocean World and the 'early modern': Historiographical conventions and problems," in Globalization. Essays in Honour of Anthony Hopkins, eds. Toyin Falola and Emily Brownell (Durham: Carolina Academic Press, 2011), 81-92, slightly revised version in Journal of Indian Ocean World Studies 1 (2017), 24-37.

${ }^{93}$ Prasannan Parthasarathi and Giorgio Riello, "The Indian Ocean in the long eighteenth century," Eighteenth Century Studies, 48, 1 (2014), 1-19; Edward A. Alpers, The Indian Ocean in World History, 98-127.

${ }^{94}$ Edward A. Alpers, "A skeptical approach to Indian Ocean cosmopolitanism," in Hommage à Philippe Beaujard, eds. Delphine Burguet, Sarah Fee, and Samuel F. Sanchez (Paris: Hémisphères Editions Maisonneuve Larose, forthcoming).

${ }^{95}$ Julia Verne, Living Translocality: Space, culture and economy in contemporary Swahili trade (Stuttgart, Fritz Steiner, 2012).

${ }^{96}$ Green, "The waves of heterotopia,": 853.

${ }^{97}$ Nile Green, "Maritime worlds and global history: Comparing the Mediterranean and Indian Ocean through Barcelona and Bombay," History Compass, 11, 7 (2013), 513-23. See also: Isabel Hofmeyr, "African history and global studies: A view from South Africa," The Journal of African History, 54, 3 (2013), 341-49.

${ }^{98}$ Sanjay Subrahmanyam, "Connected histories: Notes towards a reconfiguration of early modern Eurasia," Modern Asian Studies, 31, 3 (1997): 735-62; Sanjay Subrahmanyam, Explorations in Connected History: Tagus to the Ganges and explorations in connected history: Mughals and Franks (Delhi: Oxford University Press, 2005).
} 
historical space that evokes serious thought by those who seek to understand its past and present. $^{99}$

\section{Lingering Questions AND Ways AHEAd}

Mobility and connectivity in many guises continue to dominate Indian Ocean Studies. Whether conceived of under the rubrics of trade, commodity history, diaspora, or sacred geography and pilgrimage, these themes remain constant features of IOW historiography. The overwhelming majority of these studies, however, continue to be androcentric, largely because the sources for Indian Ocean history emphasize the role of men in commerce and religion. Nevertheless, studies of both the African and Indian diasporas have not ignored a more gendered perspective that includes women. ${ }^{100}$ Recent and forthcoming work by Hollian Wint on Gujarat merchant families in East Africa represents a pioneering venture in gendered history. ${ }^{101}$ Still, teasing out the history of women in the IOW remains a challenge that may best be pursued through the collection of life histories.

What is most encouraging about the future of Indian Ocean Studies is the recent, and growing, emergence of new centers of scholarly activity and venues for the exchange of ideas. All of these reflect the initiative of individual scholars and their ability to raise funds from within their universities and extramural funding agencies. Currently, the bestestablished academic centers are the Indian Ocean World Centre (IOWC) at McGill University in Montréal, Canada and the AEGIS Collaborative Research Group Africa in the Indian Ocean Network at Roskilde University, Denmark. ${ }^{102}$ Under the energetic leadership of Gwyn Campbell and Preben Kaarsholm, respectively, one hopes that these centers will continue to flourish institutionally beyond the tenures of their current

\footnotetext{
${ }^{99}$ Thomas McDow and I are currently writing a primer for teaching Indian Ocean world history for Duke University Press that seeks to raise these kinds of questions pedagogically.

${ }^{100}$ See, for example: Behnaz A. Mirzai, A History of Slavery and Emancipation in Oran, 1800-1929 (Austin: University of Texas Press, 2017), esp. 114-122; Helene Basu, “A gendered Indian Ocean site: Mai Mishra, African spirit possession and Sidi women in Gujarat," in Journeys and Dwellings. Indian Ocean Themes in South Asia, ed. Helene Basu (Hyderabad: Orient Longman, 2008), 227-55; Purnina Mehta Bhatt, The African Diaspora in India: Assimilation, change and cultural survivals (London: Routledge, 2018), 100-7; Marina Carter, Lakshmi's Legacy: The testimonies of Indian women in 19 ${ }^{\text {th }}$ century Mauritius (Rose-Hill, Mauritius: Editions de l'Océan Indien, 1994); Sue Peabody, Madeleine's Children: Family freedom, and lies in France's Indian Ocean colonies (New York: Oxford University Press, 2017); Kalpana Hiralal, "Voices and memories of indentured women in Natal," African Economic History, 48, 1 (2020), 74-90.

${ }^{101}$ Hollian Wint, "Keeping it in the family? Her- and his-stories among Gujarati business communities in the nineteenth century Indian Ocean," in Perspectives of Female Researchers: Interdisciplinary approaches to the study of Gujarati identities, eds. Sharmina Mawani and Anjoom A. Mukadam (Berlin: Logos Verlag Berlin, 2016), 173-88.

${ }^{102} \mathrm{https}$ ://indianoceanworldcentre.com/ and https://www.aegis-eu.org/thematic-groups/collaborative-research-group-africaindian-ocean, also https://typo3.ruc.dk/Institutter/Institut-for-Samfundsvidenskab-og-Erhverv-

\%28ISE\%29/Forskning/Store-projekter/Afsluttede-projekter/Indian-Ocean-Network [Accessed: 22 and 24 Feb. 2021].
} 
directors. Among its activities, the IOWC has since 2017 published The Journal of Indian Ocean World Studies. ${ }^{103}$

In the case of the five-year project on "Connectivity in Motion: Port Cities of the Indian Ocean" at the Max Planck Fellow Group in Halle University, Germany, the retirement of Burkhard Schnepel from the university has effectively ended its place as a center of Indian Ocean activity, although the newly established Research Centre Indian Ocean at the German University of Technology in Oman promises to become an extension of that initiative. ${ }^{104}$ Similarly, the demise of the Zanzibar Indian Ocean Research Institute (ZIORI) following the retirement of Abdul Sheriff was a real loss, although there exists the possibility that the State University of Zanzibar may take up these reins. Another wellestablished location for Indian Ocean scholarship, albeit with a focus on Africa-India interactions, is the Centre for Indian Studies in Africa (CISA) at the University of the Witwatersrand in Johannesburg, South Africa. ${ }^{105}$ Contemporary issues are addressed in the Journal of the Indian Ocean Region, which has been published since 2005. ${ }^{106}$ Information about all of these activities is made available through the Indian Ocean Studies list serve that has been moderated by Iain Walker since 2008. ${ }^{107}$

Sometimes overlooked in the predominant Anglophone world of Indian Ocean scholarship is the important Centre d'Histoire à l'Université de La Réunion, which includes the Centre de Recherches sur les Sociétés de l'Océan Indien (CRESOI) and the Commission Internationale des Historiens de l'Océan Indien. ${ }^{108}$ CRESOI supports the publication of two journals that focus on the francophone Indian Ocean: La Revue Historique de l'Océan Indien and Tsingy. Certainly, the longest established scholarly journal on the IOW in any language, however, is Études Océan Indien, which was published by the Institut Nationale des Langues et Civilisations Orientales (INALCO) in Paris from 1982 to $2014 .^{109}$

\footnotetext{
103 https://jiows.mcgill.ca/ [Accessed: 23 Feb. 2021].

${ }^{104} \mathrm{http}$ ://rio-heritage.org/ [Accessed: 22 Feb. 2021].

105 http://cisa-wits.org.za/ [Accessed: 22 Feb. 2021]. See also the older Center for South Asian and Indian Ocean Studies at Tufts University, Medford, Massachusetts, which seems less engaged with the emerging international flurry of activity: https://as.tufts.edu/csaios/, [Accessed: 22 Feb. 2021].

106 https://www.tandfonline.com/toc/rior20/current [Accessed: 19 Apr. 2021].

${ }^{107}$ Indian Ocean Studies IOSTUDIES@ JISCMAIL.AC.UK.

108 https://www.cresoi.fr/ [accessed 22 Feb. 2021].

${ }^{109}$ https://journals.openedition.org/oceanindien/ [Accessed: 23 Feb. 2021].
} 
More recent initiatives include the Leiden Centre for Indian Ocean Studies and the Indian Ocean Working Group at Georgetown University-Qatar, in Doha. ${ }^{110}$ Both sponsor regular lectures, seminars, and conferences. An exciting prospect to establish a regular platform and international organization for Indian Ocean historians was discussed energetically at the three-day Zoom conference on "The Indian Ocean World: Taking Stock, Looking Ahead" that was organized in January 2021 by historians Fahad Bishara (University of Virginia) and Ananya Chakravarti (Georgetown University). ${ }^{111}$ To an old hand like myself, this kind of gathering recalls the first ICIOS conferences in Perth. What was most encouraging to me about these well attended Zoom sessions, however, was fact that most of the participants represent the next generation of truly global Indian Ocean scholars.

To be sure, these are not the only recent initiatives in Indian Ocean Studies, while many area studies and disciplinary research centers that are not specifically focused on the Indian Ocean, such as the NYU Shanghai's Center for Global Asia, regularly host lectures and seminars on the IOW. ${ }^{112}$ For example, in the last week of March 2021, webinars on "The Black Indian Ocean," "Material Histories of the Indian Ocean World," and "Mondes insulaires de l'océan Indien" were launched, respectively, from San Francisco, George Mason University in Fairfax, Virginia, and the École des Hautes Études en Sciences Sociales in Paris.

As I mentioned previously, the big challenge is to secure solid institutional support for Indian Ocean Studies, so that whatever the shifting interests of extramural funding agencies, there remains a sound base for Indian Ocean Studies in the future. For example, today there is a novel and well-funded initiative on "Transregional Collaboratory on the Indian Ocean" funded by the Andrew E. Mellon Foundation through the Social Science Research Council. ${ }^{113}$ While it is primarily intended to encourage research among social scientists on the environment, rather than being aimed towards historians, it serves as a vivid index of the growing importance of the Indian Ocean region in a global context. For this, all scholars of the IOW must be grateful.

\footnotetext{
${ }^{110} \mathrm{https} / / / \mathrm{www}$. iias.asia/programmes/leiden-centre-indian-ocean-studies and https://www.qatar.georgetown.edu/research/research-initiatives/faculty-initiatives/indian-ocean-working-group/ [Both accessed: 22 Feb. 2021].

${ }^{111}$ https://iowconference.org/ [Accessed: 22 Feb. 2021].

${ }^{112}$ Another example is the series on "Indian Ocean Currents" organized in 2021 at the University of North Carolina at Greensboro. Tansen Sen reminds me, too, that there is great interest and research activity in Indian Ocean Studies in both China and Japan.

${ }^{113}$ https://www.ssrc.org [Accessed: 20 Apr. 2021].
} 


\section{CONCLUSION}

Let me conclude by saying something about my own trajectory as a historian of the IOW. I first studied African history as an undergraduate at Harvard College and then matriculated at SOAS for my Ph.D. But my standard SOAS thesis topic on African trade in my case focused on a then little studied part of eastern Africa that pulled me out into the Indian Ocean. To study the ivory trade in East Central Africa necessarily made me reach beyond Africa to Gujarat; to study the slave trade likewise led me to the islands of the southwest Indian Ocean, especially to Madagascar and the Mascarenes. To be perfectly honest, however, I did not really think of myself as studying the Indian Ocean. Generationally and intellectually, it was simply not in the works until the 1980s, at which time I became entangled in academic administration until the mid-1990s.

When I returned to full-time teaching, I had not only to revise all my African history lectures, but also became engaged in discussions in our department about developing a lecture course in World History. For my part, I devised new courses on the Indian Ocean and the African Diaspora. At the same time, in 1997 I was invited to present a paper on the African Diaspora to a conference on the Northwest Indian Ocean as Cultural Corridor that was organized by the University of Stockholm. ${ }^{114}$ Whereas my previous research and writing had focused on the African slave trade, thinking about the diaspora opened my eyes to the wider Indian Ocean setting of my scholarship. So, while I remain an Africanist, engaging with the broad sweep of Indian Ocean history continues to challenge my historian's imagination. I conclude by returning to Alan Villers, who wrote seventy years ago: 'The Indian is a fascinating ocean, rich in history... second to none in the story of the great lands by which it is almost, but not quite, embayed.' ${ }^{115}$

\footnotetext{
${ }^{114}$ Edward A. Alpers, "The African diaspora in the northwestern Indian Ocean: Reconsideration of an old problem, new directions for research," Comparative Studies of South Asia, Africa \& the Middle East, 17, 2 (1997), 62-81.

${ }^{115}$ Villiers, Monsoon Seas, 11.
} 